УДК 623.2 .082

(C) 2018

\author{
Підпала Т. В., доктор сільськогосподарських наук, професор, \\ Крамаренко О. С., кандидат сільськогосподарських наук, \\ Зайцев 6. М., аспірант
}

(науковий керівник - доктор сільськогосподарських наук, професор Підпала Т. В.) Миколаївський національний аграрний університет

\title{
ПРОДУКТИВНІ, ВІДТВОРЮВАЛЬНІ ТА АДАПТАЦИЙНІ ВЛАСТИВОСТІ КОРІВ ГОЛШТИНСЬКОЇ ПОРОДИ РІЗНИХ ЛІНІЙ
}

\section{Рещензент - доктор сільськогосподарських наук, професор Л. С. Патрєва}

У статті викладено результати дослідження щзодо розвитку селекційних ознак у корів різних ліній голштинської породи. Встановлено, щчо корови всіх ліній за показниками молочної продуктивності характеризуються високим рівнем їх прояву. Імпортовані корови німецької селекиії у процесі адаптації проявили достатньо високий рівень молочності та жирномолочності. Порівняно з ними, нашадки наступної генерації відрізнялися вищими надоями, але поступалися їм за вмістом жиру в молочі, за винятком ліній Старбака $і$ Чіфа. Серед корів голштинської породи української селекиії перевагу за молочною продуктивністю виявлено для тварин ліній Старбака, Маршала i Yiфa.

Ключові слова: порода, лінія, корови, молочна продуктивність, відтворювальна здатність.

Постановка проблеми. Одним із важливих селекційних прийомів створення високопродуктивних молочних стад $є$ використання кращих бугаїв і ліній [5]. Оскільки впродовж селекційного процесу в лініях, з яких складаються породи, відбувається накопичення цінної спадковості за господарськи корисними ознаками, що в свою чергу створює передумови для подальшого удосконалення. При цьому відбувається поширення спадковості як родоначальника, так і перспективних продовжувачів лінії, в результаті чого цінні властивості окремих тварин перетворюються на групові. Цей процес забезпечує прогресивний розвиток не лише окремих ліній, а й формування високопродуктивних стад і поліпшення породи в цілому $[3,4,10,11]$. Зважаючи, що генетичний потенціал продуктивності тварин підвищується переважно завдяки використанню генофонду голштинської породи, то й дослідження його реалізації у корів, що належать до різних ліній, $\mathrm{\epsilon}$ актуальним.

Аналіз останніх досліджень і публікацій, у яких започатковано розв'язання проблеми. Селекційний прогрес з удосконалення молочної худоби відповідно до сучасних вимог підтриму- ється одним 3 ефективних методів, застосовуваних в селекції - це розведення за лініями. В процесі застосування лінійного розведення відбувається перетворення цінних властивостей на групові не лише високоцінних бугаїв-плідників, а й корів із рекордною продуктивністю.

Вивченням продуктивних, технологічних, адаптаційних властивостей корів голштинської породи різних ліній займалися учені $[1,6,7,12]$. Т. В. Литвиненко, О. Г. Тимченко [7], які встановили, що корови досліджуваних дев'яти ліній голштинської породи характеризуються високою живою масою (570-680 кг), з надоєм 6514-7791 кг молока за враховані лактації з вмістом жиру 3,84-4,04 \%, кількістю молочного жиру - 250307 кг і коефіцієнтом молочності - 1098-1296 кг. Проте серед них найвищі показники продуктивності мали корови лінії Монтвік Чіфтейна, а нижчі - тварини лінії Рігела і Старбака. Для корів лінії Старбака встановлено також найкоротша тривалість життя і найнижчі коефіцієнти господарського використання. За показниками продуктивного використання, що проявилися у тварин голштинської породи у процесі пристосування до нових еколого-господарських умов утримання й експлуатації, найбільш довговічними були дочки плідників лінії Елевейшна [12]. Отже, розвиток селекційних ознак у поколіннях молочної худоби детермінується, в першу чергу, генотипом тварин, зокрема належністю до породи та лінії [9].

Проте $є$ суперечливість між результатами, що отримані в господарствах із розведення молочної худоби голштинської породи різних ліній. Це, в свою чергу, вказує на необхідність досліджень щодо реалізації спадкових можливостей тваринами різної лінійної належності й особливо в умовах інтенсивної технології виробництва молока.

Мета досліджень - оцінити продуктивні, відтворювальні та адаптаційні властивості корів різних ліній голштинської породи. 


\section{СІЛЬСЬКЕ ГОСПОДАРСТВО. ТВАРИННИЦТВО}

Зазначена мета виконувалася через такі завдання: визначити розвиток господарськи корисних ознак у імпортованих корів голштинської породи різних ліній; встановити прояв селекційних ознак у корів наступної генерації, розподілених згідно з належністю до ліній; оцінити реалізацію спадковості голштинської породи української селекції за продуктивністю первісток суміжних поколінь, які належать до різних ліній.

Матеріали і методи досліджень. У племінному заводі СТОВ «Промінь» Миколаївської області було сформовано дослідні групи з корівпервісток голштинської породи: перша - імпортовані тварини з Німеччини $(\mathrm{n}=181)$; друга - їх дочки, тобто тварини власної репродукції $(\mathrm{n}=181)$; третя - тварини української селекції $(n=175)$ і четверта - ïx дочки $(n=175)$. За даними електронної інформаційної бази племінного обліку визначили походження корів і розподілили їх на групи згідно з лінійною належністю.

Матеріалом для дослідження були дані молочної продуктивності корів-первісток різних ліній голштинської породи. Піддослідних тварин оцінювали також за відтворювальною здатністю, зокрема: тривалістю сервіс-періоду (СП), міжотельного періоду (МОП), сухостійного періоду (СхП) і за коефіцієнтом відтворювальної здатності (КВ3), а адаптаційні властивості - за індексом адаптації (IA). Для порівняльної оцінки рівня розвитку селекційних ознак у корів різних ліній голштинської породи визначали популяційно-генетичні параметри, використовуючи методи варіаційної статистики [8].

Результати досліджень. Нашими дослідженнями встановлено рівень розвитку господарськи корисних ознак корів голштинської породи німецької та української селекції, що належать до різних ліній. Імпортовані корови німецької селекції у процесі адаптації проявили достатньо високий рівень молочності та жирномолочності. Порівняно 3 ними нащадки наступної генерації відрізнялися вищими надоями, але поступалися їм за вмістом жиру в молоці, за винятком ліній Старбака 352790 і Чіфа 1427381.

Серед корів досліджуваних ліній вищим рівнем надою характеризувалися тварини ліній Валіанта 1650414, Дж. Бесна 5694028588, Маршала 2290977, Белла 1667366 і Елівейшна 1491007. Порівняно з лінією Чіфа 1427381 першого генетико-екологічного покоління (матері) їх перевага за величиною надою за лактацію становила 1622 кг, 921 кг (Р>0,95), 908 кг, 899 кг і 478 кг відповідно. Щодо вмісту жиру в молоці, то у корів різної лінійної належності цей показник коливався в межах 3,91-3,96 \%. Проте за кількістю молочно- го жиру за лактацію перевагу мали корови цих ліній, але 3 деякою зміною їх послідовності: Валіанта 1650414, Маршала 2290977, Белла 1667366, Дж. Бесна 5694028588 і Елівейшна 1491007. Їх різниця за кількістю молочного жиру порівняно з коровами лінії Чіфа 1427381 становила 65,8 кг, 36,6 кг, 36,4 кг, 32,8 кг і 16,7 кг. Встановлено перевагу цих ліній також і за кількістю молочного білка за лактацію. Корови ліній Валіанта 1650414, Маршала 2290977, Дж. Бесна 5694028588, Белла 1667366 і Елівейшна 1491007 мали цей показник вищий на 48,3 кг (Р>0,99), 27,7 кг, 27,4 кг, 25,6 кг і 14,9 кг відповідно. Найбільшим показником кількості молочного жиру за добу характеризуються корови, що належать до лінії Маршала 2290977. Їх різниця порівняно 3 тваринами лінії Чіфа 1427381 становила 0,08 кг.

Аналогічні результати щодо прояву молочної продуктивності коровами голштинської породи канадської селекції в процесі адаптації встановлені Л. М. Хмельничим та іншими [2].

Корови другого генетико-екологічного покоління (дочки) досліджуваних ліній відрізняються вищими показниками молочної продуктивності (9276-11235 кг). Встановлено й відмінності за розвитком господарськи корисних ознак корів різної лінійної належності. Так, вищим рівнем молочної продуктивності характеризувалися корови ліній Старбака 352790, Чіфа 1427381 та Елівейшна 1491007, які були більш чисельними за поголів'ям. Різниця за величиною надою за лактацію порівняно 3 лінією Валіанта 1650414 становила 1289 кг, 755 кг і 747 кг відповідно. Встановлена перевага тварин цих ліній за іншими показниками молочної продуктивності: за кількістю молочного жиру різниця становила 58,2 кг (P>0,95), 38,3 кг і 30,6 кг, за кількістю молочного білка 43,5 кг (P>0,99), 26,8 кг і 24,1 кг відповідно.

Разом із тим, у тварин спостерігається істотне, в порівнянні з фізіологічними та економічно обгрунтованими нормами, подовження тривалості сервіс-періоду та міжотельного періоду, особливо у корів II ГЕП. Найбільші значення цих показників мають корови ліній Старбака 352790, Елівейшна 1491007 і Чіфа 1427381 (117,1-110,5 днів). Серед корів II ГЕП кращою пристосованістю характеризувалися первістки, які належали до лінії Валіанта 1650414, індекс адаптації у яких був 1,44. Щодо тварин ліній Старбака 352790 і Елівейшна 1491007, то у них IA становив -0,53 і -0,93, тобто незначно відрізняється від оптимального значення.

Аналогічно, високою продуктивністю харак- 


\section{СІЛЬСЬКЕ ГОСПОДАРСТВО. ТВАРИННИЦТВО}

теризувалися корови голштинської породи української селекції та за проявом ознак перевагу також мали дочки. Встановлено, що матері належать до більшої кількості ліній, які за показниками надою за лактацію, вмісту і кількості молочного жиру, вмісту і кількості молочного білка розташувалися у порядку від вищих показників до нижчих у такій послідовності: Елівейшна 1491007, Маршала 2290977, Старбака 352790, Хеневе 1667366, Чіфа 1427381. Особливістю їх дочок $є$ те, що вони належать до значно меншої кількості ліній і це вказує на спрямованість селекційного процесу під час створення високопродуктивного стада. За рівнем прояву ознак молочної продуктивності у корів послідовність ліній наступна: Старбака 352790, Маршала 2290977 і Чіфа 1427381.

Проте як у голштинів німецької селекції, так i у тварин голштинської породи української селекції спостерігається подовження тривалості міжотельного та сервіс-періодів. Найбільшою тривалістю сервіс-періоду характеризуються корови-матері ліній Елівейшна 1491007 і Старбака 352790, а дочки ліній - Старбака 352790 і Чіфа 1427381. Аналогічно, вони мають і більшу тривалість міжотельного періоду. За індексом адаптації кращі показники мають корови лінії Маршала 2290977, як матері, так і дочки.

У результаті досліджень 3 використанням дисперсійного аналізу встановлено вірогідний

\section{БІБЛІОГРАФІЯ}

1. Адаптаційна здатність корів голштинської та української чорно-рябої молочної порід / [Засуха Т. В. та ін.] // Розведення і генетика тварин : міжвідом. тематич. наук. зб. - К. : Аграрна наука, 2005. - Вип. 38. - С. 148-151.

2. Адаптаційна здатність корів різного генетико-екологічного походження / [Хмельничий Л. М., Вечорка В. В., Бондарчук В. М. та ін.] // Вісник Сумського національного аграрного університету : науково-методичний журнал : серія «Тваринництво». - Суми, 2016. - Вип. 7(30). - С. 121-125.

3. Базишина I. В. Формування господарськи корисних ознак молочної худоби залежно від походження за батьком, лінії та спорідненої групи / І. В. Базишина // Розведення і генетика тварин : міжвідом. тематич. наук. зб. - К. : ФОП Рибаченко О. М., 2017. - Вип. 53. - С. 69-78.

4. Бойко Ю. М. Перспектива селекції худоби української бурої молочної породи в аспекті лінійного розведення 3 врахуванням світових тенденцій тривалості ліній у поколіннях / Ю. М. Бойко // Вісник Сумського національного аграрного університету : науково-методичний вплив лінійної належності на прояв окремих селекційних ознак, зокрема: надій, кількість молочного жиру за лактацію і добу, кількість молочного білка. Для корів-дочок голштинської породи української селекції доведено існування достовірного впливу лінійної належності на розвиток такої ознаки, як вміст білка в молоці. Це, в свою чергу, підтверджує не лише доцільність використання лінійного розведення у селекційно-племінній роботі, а й характеризує напрям поліпшуючої селекції в даному стаді.

\section{Висновки:}

1. Встановлено рівень розвитку господарськи корисних ознак корів голштинської породи німецької та української селекції, що належать до різних ліній. Імпортовані корови німецької селекції у процесі адаптації проявили достатньо високий рівень молочності та жирномолочності.

2. Вищим рівнем надою, кількості молочного жиру і білка характеризувалися тварини ліній Валіанта 1650414, Дж. Бесна 5694028588, Маршала 2290977, Белла 1667366 і Елівейшна 1491007.

3. За проявом продуктивних ознак у тварин голштинської породи української селекції кращими були корови-матері ліній Елівейшна 1491007, Маршала 2290977, Старбака 352790 i дочки ліній Старбака 352790 і Маршала 2290977. Корови цих ліній мають подовжену тривалість сервіс-періоду і міжотельного періоду.

журнал : серія «Тваринництво». - Суми, 2013. Вип. 1 (22). - С. 20-26.

5. Дідківський $B$. О. Селекційно-генетичні аспекти створення високопродуктивного молочного стада : автореф. дис. на здобуття наук. ступеня к. с.-г. н. : спец. 06.02.01 «Розведення та селекція тварин» / В. О. Дідківський. - КиївЧубинське, 2007. - 20 с.

6. Катмаков П. С. Молочная продуктивность и воспроизводительная способность коров черно-пестрой и голштинской пород разных генеалогических линий / П. С. Катмаков, Л. В. Анфимова, О. М. Кузьмина // Вісник Сумського національного аграрного університету : науковий журнал : серія «Тваринництво». - Суми, 2012. - Вип. 10 (20). - С. 40-42.

7. Литвиненко Т. В., Тимченко О. Г. Продуктивність корів голштинської породи різних ліній / Т. В. Литвиненко, О. Г. Тимченко // Розведення і генетика тварин : міжвідом. тематич. наук. зб. К. : Аграрна наука, 2005. - Вип. 38. - С. 164-166. 


\section{СІЛЬСЬКЕ ГОСПОДАРСТВО. ТВАРИННИЦТВО}

8. Меркурьева E. K. Биометрия в селекции и генетике сельскохозяйственных животных / Е. К. Меркурьева. - М. : Колос, 1970. - 422 с.

9. Пелехатий М. С., Кальчук Л. А. Результати господарського використання корів чорно-рябої породи різного походження, генотипів і ліній / М. С. Пелехатий, Л. А. Кальчук // Науковотехнічний бюлетень Інституту тваринництва УААН. - Х., 2001. - №80. - С. 88-90.

10. Ставецька Р. В. Методи підвищення ефективності селекції популяцій молочної худоби : автореф. дис. на здобуття наук. ступеня д. с.-г. н. : спец. 06.02.01 «Розведення та селекція тварин»/
Р. В. Ставецька. - с. Чубинське Київської області, 2013. - 39 с.

11. Хмельничий Л. М., Лобода В. П. Удосконалення стада 3 розведення української червонорябої молочної породи за показниками довічної продуктивності / Л. М. Хмельничий, В. П. Лобода // Вісник Сумського національного аграрного університету : науковий журнал : серія «Тваринництво». - Суми, 2014. - Вип. 2/1 (24). - С. 9197.

12. Шкурко T. Продуктивне використання голштинських корів різних ліній / Т. Шкурко // Тваринництво України. - 2009. - №10. - С. 1315. 